\title{
History of Education
}

\section{John Dewey and American Democracy}

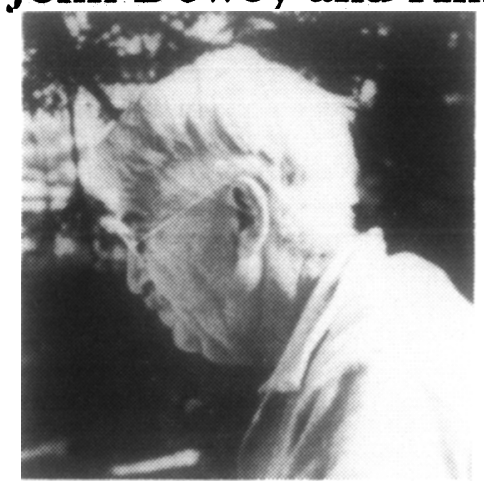

\section{Sons and Daughters of Labor}

Class and Clerical Work in Turn-of-the-Century Pittsburgh

By ILEEN A. DEVAULT. "DeVault has created a rich analysis of the recruitment, training, and careers of clerical workers during the epoch in which their numbers expanded decisively."-David Montgomery, Yale University. DeVault tracks the paths of public high school students through their vocational or commercial training in Pittsburgh's public high school commercial education program, and follows their eventual job careers. $\$ 21.50$

\section{The Battle of the} Books

\section{History and Literature in} the Augustan Age

By JOSEPH M. LEVINE. Levine provides a witty and erudite account of one of the most celebrated chapters in English cultural history, the acrimonious quarrel between the "ancients" and the "moderns" which Jonathan Swift dubbed "the Battle of the Books." \$29.95

BY ROBERT B. WESTBROOK.

"Westbrook has written a magisterial book about America's foremost philosopher of the twentieth century, perhaps of any century. Deeply researched and carefully crafted, it is intellectual history at its most scintillating. It will be the standard for measuring not only future work on Dewey but future work in intellectual biography in general."

-Richard W. Fox, Boston University. $\$ 29.95$

\section{Blackboard Unions The AFT and the NEA, 1900-1980}

BY MARJORIE MURPHY. "There is simply no better account of teachers' organizations in the twentieth century than this superbly written study. Finally, here is a book that makes teachers political activists instead of pawns in the hands of local forces." -Paul H. Mattingly, New York University. \$28.95

\section{Physics as a Calling} Discipline and Practice in the Königsberg Seminar for Physics

BY KATHRYN M. OLESKO. In this book, Olesko reconstructs in fine detail the evolution, across the nineteenth century, of Franz Neumann's physics seminar at Königsberg University in East Prussia. $\$ 39.95$

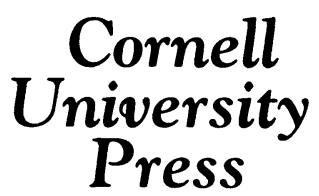

124 Roberts Place Ithaca, NY 14850 


\section{To Our Contributors}

Format for submissions:

1. All copy should be typed double-spaced, including between and within footnotes. Allow approximately a one-inch margin on all four sides of the page.

2. Preferred article length is 25 pages, exclusive of footnotes.

3. Authors should use a type size that is no smaller than elite type.

4. Two copies of the manuscript should be submitted on white paper, addressed to the History of Education Quarterly, School of Education, Indiana University, Bloomington, IN 47405. Manuscripts are not returned unless article is accompanied by self-addressed envelope with sufficient postage.

5. Footnotes should be listed in a separate section at the end of the articles. The following format should be used for references:

Book:

'Neil Coughlan, Young John Dewey: An Essay in American Intellectual History (Chicago, 1972), 92.

Edited Book:

${ }^{2}$ Pierre Bourdieu, "Cultural Reproduction and Social Reproduction," in Knowledge, Education, and Cultural Change, ed. Richard Brown (London, 1973), 71-112.

Journal Article:

3John Rury and Glenn Harper, "The Trouble with Coeducation: Mann and Women at Antioch, 1853-1860," History of Education Quurterly 26 (Winter 1986): 481-502.

Popular Magazine Article:

${ }^{4}$ W. Caspari and R. E. Marshak, "The Rise and Fall of Lysenko," Science, 16 Aug. 1965, 275-78.

Unpublished Work:

sRichard Simon, "Comedy, Suffering, and Human Existence" (Ph.D. diss., Stanford University, 1977), 100-102.

\section{Manuscript:}

'Hiram Johnson to John Callan O'Laughlin, 16 July 1916, file 6 box 20, O'Laughlin Papers, Roosevelt Memorial Collection, Harvard College Library.

The style of the History of Education Quarterly conforms very closely to The Chicago Manual of Style, 13th ed. (Chicago, 1982). Authors should consult this manual if they have further questions. 